\title{
Choumiryou dan Harapan Hidup Orang Jepang
}

\author{
S.I. Trahutami \\ Sekolah Vokasi, Universitas Diponegoro Semarang \\ Jl. Prof. Soedarto, SH. Tembalang Semarang 50275 \\ Email: Utami_undip@yahoo.com
}

\begin{abstract}
The life expectancy of Japanese is the highest in the world, an average of $83-84$ years. This makes Japan a world role model in order to be able to live long and healthy lives. Many factors influence the high life expectancy of Japanese, one of which is food. Japanese food or washoku (和 食) has already become widely known and widely accepted. Along with this, Japanese basic ingredients or choumiryou (調味 料) are becoming well known. The purpose of this study is to describe the influence of choumiryou on the high life expectancy of Japanese. This study used descriptive qualitative method. The results of this study indicate that basic choumiryou has a large influence on the health of Japanese people. Although some basic spices are not good for health, this does not prevent Japanese from consuming them. Japanese consume choumiryou in a safe portion that does not damage health. In addition, the role of the basic choumiryou in the high life expectancy of Japanese people can also be seen from various kinds of substances that are good for health contained in the basic sashisuseso choumiryou. The taste of choumiryou has always been maintained by the Japanese for the sake of acquiring a distinctive Japanese flavor that has a characteristic soft taste.
\end{abstract}

Keywords: Choumiryou, Life Expectancy, Cuisine, Spices, Sashisuseso

\section{Pendahuluan}

Harapan hidup orang Jepang adalah yang tertinggi di dunia, yakni rata-rata 83 - 84 tahun. Hal ini tentu saja membuat Jepang menjadi sebuah role model dunia untuk dapat hidup panjang umur dan sehat. Banyak faktor yang mempengaruhi tingginya harapan hidup orang Jepang, salah satunya adalah makanan. Makanan khas Jepang atau washoku (和食) sudah mulai banyak dikenal dan diterima secara luas. Seiring dengan hal tersebut bumbu atau choumiryou (調味料) dasar masakan Jepang pun mulai dikenal.

Beberapa penelitian mengenai masakan Jepang telah dilakukan sebelumnya. Diantaranya adalah oleh Ross (2011) dan Poto (2010). Dalam artikel jurnalnya, Ross membahas mengenai kebiasaaan makan imigran Jepang dan China di pengalengan Salmon British Columbia. Hasil dari penelitian tersebut menunjukkan bahwa bahwa pekerja pengalengan Jepang mengkonsumsi kombinasi makanan gaya Asia dan Barat, sementara orang Cina sangat bergantung pada makanan tradisional. Di sisi lain Poto meneliti tentang hukum yang mengatur pangan di Jepang. Hasil dari penelitian ini adalah berupa pemetaan persamaan dan perbedaan sistem hukum pangan di Jepang, dibandingkan dengan di China dan Eropa. Penelitian ini dengan dua penelitian sebelumnya sama-sama bertemakan makanan Jepang, namun pada penelitian ini memfokuskan kepada choumiryou masakan orang Jepang yang dapat mempengaruhi harapan hidup.

Permasalahan dalam penelitian ini adalah bagaimana pengaruh choumiryou terhadap harapan hidup orang Jepang? Penelitian ini bertujuan untuk mendeskripsikan bagaimana 
pengaruh choumiryou hingga dapat mempengaruhi kesehatan yang berdampak pada harapan hidup tinggi orang Jepang. Penelitian ini diharapkan dapat memberikan deskripsi mengenai pengaruh choumiryou melalui masakan-masakan Jepang. Selain itu akan dideskripsikan pula bagaimana orang Jepang mengolah choumiryou yang ada, hingga menjadi berbagai varian masakan. Olahan-olahan dengan choumiryou tersebut tentunya dapat menjadi suatu representatif dalam memahami karakter masakan Jepang hingga banyak warganya yang berumur panjang.

\section{Metode}

Penelitian ini menggunakan metode deskriptif melalui pendekatan kualitatif. Untuk melakukan penelitian ini, dilakukan tiga tahapan, yakni tahap pengumpulan data, tahap analisis data, dan tahap penyajian hasil. Metode yang digunakan untuk mengumpulkan data adalah metode kepustakaan. Metode kepustakaan merupakan metode penelitian yang bertujuan untuk mengumpulkan data dan informasi dengan bantuan bermacam-macam material yang terdapat di ruangan perpustakaan, seperti buku-buku, majalah, dokumen, catatan dan kisah-kisah sejarah dan lain-lain (Mardalis, 1999: 28). Teknik yang digunakan adalah teknik dokumentasi, yaitu teknik pengumpulan data melalui text reading, pengkajian, dan pencatatan segala pustaka yang berhubungan dengan penelitian ini.

Sebagai upaya untuk mengumpulkan data, penulis mendokumentasikan beberapa sumber tertulis serta melakukan observasi terhadap fenomena penggunaan choumiryou. Sumber tertulis yang dikaji adalah berupa artikel jurnal dan buku. Sedangkan observasi dilakukan melalui fenomena penggunaan choumiryou pada masakan Jepang yang ditelaah berdasarkan resep masakan. Penulis memilih choumiryou sebagai objek observasi karena choumiryou merupakan faktor penting dalam menjawab tingginya angka harapan hidup di Jepang. Selain itu choumiryou dipilih karena maraknya perkembangan masakan Jepang belakangan ini di dunia internasional, sehingga kedudukan choumiryou pada dasarnya pada masakan Jepang sangat diperhitungkan karena mempengaruhi rasa dari masakan yang dihasilkan.

Tahap selanjutnya yakni tahap analisis. Data dianalisis dengan metode deskriptif kualitatif. Deskripsi dilakukan dengan memaparkan fakta berdasarkan data yang berwujud non angka untuk menjawab masalah dalam penelitian ini. Dengan menggunakan data yang terkumpul, penulis akan mendeskripsikan pengaruh choumiryou dalam masakan Jepang sehingga menghasilkan masakan yang sehat. Hasil yang dicapai dalam penelitian ini akan disajikan dalam bentuk deskripsi, sehingga melalui proses di atas, diharapkan tujuan dalam penelitian ini dapat tercapai.

\section{Hasil dan Pembahasan}

\subsection{Esensi Choumiryou}

Seperti halnya bumbu dasar masakan di berbagai negara, Jepang pun memiliki bumbu atau choumiryou dasar sebagai ciri yang menjadikan cita rasa masakan Jepang sangat melekat. Choumiryou dasar yang dipakai orang Jepang sejatinya familiar dengan sebutan choumiryou no sashisuseso (調味料のさしすせそ) atau bumbu sashisuseso. Sa merupakan kependekan dari satou (佐藤) 'gula', shi adalah shio (塩) 'garam', su (酢) 'cuka', se merupakan kependekan dari shouyu (奨油) 'saus kedelai', dan so merupakan kependekan dari miso (味噌). Kelima bumbu dasar Jepang tersebut pada zaman dahulu wajib untuk ditambahkan ke dalam masakan secara berurutan, namun seiring perkembangan zaman dan makin bervariasinya masakan Jepang, bumbu-bumbu tersebut minimal salah satunya wajib untuk ditambahkan pada setiap masakan Jepang. Bahkan orang Jepang merasa jika salah satunya tidak dimasukkan dalam olahan masakan, dirasa ada yang kurang lengkap dalam cita rasanya.

Peran penting kelima choumiryou tersebut adalah sebagai berikut. Pertama, Satou. Satou 'gula' merupakan choumiryou yang pertama kali ditambahkan dalam masakan. Sifat gula yang dianggap lama dalam penyerapan ke dalam masakan dibandingkan bumbu lainnya menyebabkan 
gula adalah bumbu yang pertama kali ditambahkan. Gula banyak dipakai untuk membuat kue di Jepang. Bagi sebagian besar orang asing, kue Jepang bahkan dianggap terlalu manis. Hal ini sejatinya berawal dari dibuatnya kue sebagai pendamping dalam tradisi upacara minum teh atau sadou (茶道) untuk menetralisir rasa pahit pada teh yang kemudian terus berkembang variannya hingga merambah ke kue yang dinikmati sebagai makanan ringan.

Kedua, Shio. Shio 'garam' diperlukan dalam proses memasak untuk mengeluarkan kandungan air dalam masakan. Garam ditambahkan ke masakkan setelah gula untuk menghindari agar masakan tidak menjadi keras. Selain itu, hal tersebut bertujuan untuk memudahkan penyerapan gula ke dalam masakan. Garam juga dipercaya orang Jepang dapat menambah rasa manis. Sebagai contoh di Jepang biasanya semangka dinikmati dengan dibubuhi garam di atasnya sehingga rasa yang pertama kali dirasakan adalah asin, kemudian diikuti dengan rasa manis dari semangka, hal tersebut menjadikan rasa semangka akan terasa lebih manis daripada rasa aslinya.

Ketiga, Su. Su 'cuka' pada masakan Jepang biasanya ditambahkan menjelang masakan hampir matang. Di Jepang terdapat berbagai macam cuka dengan berbagai variasinya, diantaranya adalah kokumotsusu (款物酢）， komesu（米酢）, junmaisu（純米酢）, dll. Pada Sushi, cuka dipakai sebagai anti bakteri pada bahan mentah, sedangkan pada Namasu, cuka dikonsumsi sekaligus sebagai saus cuka. Bahkan telah menjadi kebiasaan masyarakat Jepang untuk sarapan dengan masakan yang berbahan fermentasi, salah satunya adalah penambahan cuka dalam menu sarapan. Menu sarapan unik orang Jepang juga dipercaya sebagai salah satu faktor yang menyebaban orang Jepang jarang mengalami obesitas.

Keempat, Shouyu. Shouyu atau yang biasa disebut dengan kecap Jepang terbuat dari fermentasi kedelai, tepung, dan garam. Shouyu sangat akrab bagi pecinta masakan Jepang karena selalu ada dalam hidangan seperti yakiniku, sushi, sashimi, dll. Berbeda dengan cita rasa kecap di Indonesia yang umumnya hanya mengenal dua macam rasa, yakni manis dan asin, shouyu memiliki rasa umami (旨味). Rasa umami merupakan rasa kelima yang diusulkan oleh seorang ilmuwan Jepang pada tahun 1908. Umami merupakan jenis rasa gurih sebagai tambahan diantara rasa manis, pahit, asin, dan asam.

Kelima, Miso. Seperti halnya shouyu, miso pun terbuat dari bahan fermentasi, yakni fermentasi rebusan kedelai, beras, dan garam. Miso dijadikan sebagai bumbu yang terakhir ditambahkan dalam masakan karena aromanya mudah hilang, sehingga kompor harus segera dimatikan saat masakan mendidih. Masyarakat Jepang terbiasa mengonsumsi miso shiru (味噌 汁) 'sup miso' sebagai sarapan pendamping nasi dan lauk. Miso sup sengaja dihidangkan untuk menambah nafsu makan, sumber protein, dan sumber garam. Di Jepang terdapat berbagai variasi miso tergantung pada perbedaan bahan, kultur masyarakat yang membuat, serta perbedaan durasi fermentasi.

\subsection{Choumiryou dalam masakan Jepang}

Berbagai masakan yang dikonsumsi orang Jepang pada umumnya mengandung choumiryou dasar seperti pada penjelasan di atas, diantaranya adalah sebagai berikut:

Pertama, Onigiri. Onigiri atau nasi kepal ala Jepang sangat populer sebagai salah satu ikon masakan Jepang. untuk membuat onigiri, choumiryou dasar yang digunakan adalah garam dan shouyu. Garam ditaburkan di nasi sebelum dikepalkan untuk menghilangkan rasa hambar, sehingga nasi terasa asin. Selain itu, orang Jepang juga menambahkan shouyu sebagai olesan pada onigiri untuk menambahkan rasa gurih di dalamnya. Onigiri hampir setiap hari dikonsumsi oleh orang Jepang, terutama dijadikan salah satu menu dalam bentou (弁当) 'bekal makan'. Untuk memenuhi kebutuhan protein pada onigiri, sering pula ditambahkan ikan tuna, ikan salmon, ayam, dll. Dengan demikian tidak hanya kebutuhan tubuh terhadap karbohidrat saja yang terpenuhi, namun protein hewani juga dapat terpenuhi. Seringkali onigiri juga dibalutkan pada nori atau rumput laut kering, sehingga dapat menambah kandungan gizi dalam sekepal onigiri. 
Kedua, Wagashi. Wagashi (和菓子) 'kue Jepang' merupakan sebutan untuk berbagai jenis kue khas Jepang yang disajikan pada upacara minum teh. Dalam proses pembuatannya, wagashi sengaja dibuat menggunakan gula yang cukup banyak. Wagashi pada umumnya dibuat dengan berbagai macam corak warna dengan berbagai maknanya masing-masing. Contohnya adalah wagashi dengan warna hijau. Warna hijau pada wagashi melambangkan rerumputan sebagai simbol kesehatan dan panjang umur. Selain itu warna coklat juga juga merupakan warna yang melambangkan kesehatan, kesederhanaan, alam, dll.

Ketiga, Sushi. Dalam pembuatan sushi, cuka memiliki peran yang sangat penting, yakni sebagai anti bakteri. Sushi merupakan masakan khas Jepang yang dibuat dengan bahan dasar ikan mentah, oleh karena itu diperlukan sebuah bahan anti bakteri agar ikan mentah menjadi aman untuk dikonsumsi. Cuka biasanya dituangkan dalam sebuah mangkok untuk kemudian dioleskan di tangan yang telah bersih pada saat proses pembuatan sushi. Namun demikian perlu diingat bahwa cuka yang dioleskan di tangan hendaklah tidak terlalu banyak karena akan merusak rasa sehingga sushi menjadi terlalu asam. Sushi yang asam karena terlalu banyak mengandung cuka di dalamnya tentunya tidak baik bagi tubuh karena dapat menimbulkan gangguan pencernaan.

Keempat, Sashimi. Sashimi merupakan masakan Jepang populer lain selain sushi yang juga berbahan mentah ikan mentah. Sashimi disajikan dengan cara memotong tipis ikan salmon atau ikan tuna mentah yang masih segar dengan menambahkan shouyu dan perasan lemon. Shouyu dikonsumsi bersamaan dengan sashimi dengan cara mencelupkan sedikit bagian dari sashimi ke dalam shouyu. Hal ini dilakukan agar cita rasa dari kesegaran ikan mentah pada sashimi diharapkan tetap mendominasi saat dikonsumsi, sehingga shouyu bersifat sebagai pelengkap saja untuk menambahkan rasa umami. Tidak hanya shouyu, perasan lemon juga dipakai untuk menambah sensasi ikan segar pada sashimi, sehingga rasa ikan mentah yang terkesan lembut, shouyu yang gurih, serta perasan lemon yang menyegarkan dapat dinikmati sekaligus dalam satu suapan.

Kelima, Ramen. Ramen merupakan salah satu masakan populer dari Jepang. Ramen dibuat bervariasi berdasarkan isi dan kuahnya. Miso atau yang di Indonesia sering disebut dengan tauco Jepang memiliki cita rasa cenderung asin dan sedikit manis. Salah satu ramen yang paling disukai di Jepang adalah ramen yang dibuat dengan kuah miso dan sering disebut dengan miso ramen. Miso ramen mulai populer pada tahun pertengahan 1960-an serta berawal dari Hokaido utara.

\subsection{Peran Choumiryou untuk kesehatan}

Maraknya berbagai penyakit yang timbul karena makanan menjadi perhatian khusus di Jepang. Orang Jepang sudah sejak lama sangat memperhatikan asupan makanan demi kesehatan. Bahkan gula yang sejatinya termasuk ke dalam salah satu choumiryou dasar mereka dikonsumsi sangat terbatas. Pada umumnya orang Jepang tidak menambahkan gula saat mengonsumsi kopi dan teh. Nasi yang setiap hari dikonsumsi pun hanya dalam porsi yang kecil sehingga dapat meminimalisir asupan gula ke dalam tubuh.

Selain gula, orang Jepang juga membatasi asupan garam meskipun juga termasuk ke dalam salah satu choumiryou dasar. Garam dalam masakan biasanya digunakan hanya sebagai taburan atau pelengkap. Orang Jepang mengolah garam bersama dengan bahan lainnya untuk dikonsumsi menjadi makanan pokok. Hal ini berarti bahwa orang Jepang tetap membutuhkan sensasi rasa asin dalam masakannya untuk mengambil manfaat natrium dalam garam secukupnya. Selain itu, orang Jepang justru lebih banyak memanfaatkan garam untuk ritual dan kepercayaan tradisional.

Cuka termasuk salah satu bahan yang memegang peran penting dalam menjaga kesehatan orang Jepang. Selama ini Jepang dikenal dengan masyarakatnya yang bertubuh langsing dan ideal. Hal ini tentunya tidak lepas dari peran cuka yang menjadi choumiryou dasar dalam masakan Jepang sehari-hari. Berbagai penelitian pun telah dilakukan terkait dengan manfaat cuka untuk kesehatan, salah satunya untuk membuat tubuh menjadi langsing sehingga memiliki 
berat badan yang ideal. Salah satu jenis cuka yang telah dikenal memiliki manfaat tersebut adalah cuka apel.

Shouyu merupakan salah satu choumiryou dasar yang dipercaya orang Jepang dapat menjaga kesehatan. Hal tersebut dikarenakan shouyu termasuk salah satu hasil dari makanan fermentasi kedelai yang kaya akan protein, vitamin, dan mineral. Mengonsumsi kedelai dipercaya dapat menjaga jantung, menurunkan kolesterol, serta dapat mencegah kanker payudara. Di Jepang sendiri terdapat berbagai macam shouyu yang dibedakan tergantung bagaimana proses fermentasi dilakukan. Proses fermentasi dapat berbeda-beda di setiap daerah di Jepang, tergantung tradisi setempat dan tentu saja faktor cuaca yang mempengaruhi kelembapan udara.

Miso yang pada umumnya ditambahkan pada sup sebagai sarapan wajib orang Jepang memiliki berbagai manfaat, yakni menjaga kesehatan usus, menjaga kesehatan jantung, memperkuat tulang, dan mencegah pertumbuhan sel kanker. Miso sup sendiri sebenarnya dapat dibuat sendiri di rumah, hal itulah yang menyebabkan miso sup menjadi menu wajib sarapan, karena selain cara membuatnya mudah, bahannya pun juga murah dan mudah diperoleh. Variasi miso sup pada hidangan sarapan orang Jepang pun bervariasi, ada yang dibuat dengan isian tahu, isia jamur, dll. Seiring dengan berkembangnya masakan Jepang di seluruh dunia, maka miso tidak hanya sekedar dijadikan bahan pencampur sup, namun juga masakan barat seperti spaghetti bolognese dan salad. Hal tersebut menunjukkan bahwa miso yang dipercaya orang Jepang memiliki banyak manfaat untuk kesehatan telah mulai diadaptasi oleh bangsa lain untuk diambil manfaatnya dan diaplikkasikan pada masakannya.

\section{Simpulan}

Berdasarkan uraian di atas maka dapat disimpulkan bahwa, choumiryou dasar memiliki pengaruh yang besar terhadap kesehatan orang Jepang, sehingga harapan hidup orang Jepang menjadi tinggi. Beberapa choumiryou dasar merupakan pantangan bagi kesehatan, namun hal tersebut tidak menghalangi orang Jepang untuk mengonsumsinya. Orang Jepang mengonsumsi choumiryou dalam porsi yang aman sehingga tidak merusak kesehatan. Selain itu, peran choumiryou dasar dalam tingginya harapan hidup orang Jepang juga dapat dilihat dari berbagai macam kandungan zat yang baik untuk kesehatan yang terkandung di dalam choumiryou dasar sashisuseso. Cita rasa choumiryou tersebut selalu dipertahaankan orang Jepang demi memperoleh cita rasa khas Jepang yang memiliki ciri rasa yang lembut.

Selain masakan, tentu saja harapan hidup tinggi orang Jepang pun dipengaruhi oleh beberapa faktor lain, diantaranya adalah pola hidup. Orang Jepang dikenal sebagai bangsa yang senang berjalan kaki dan bersepeda. Meskipun transportasi sudah sangat praktis, namun kebanyakan orang Jepang lebih memilih untuk berjalan kaki atau bersepeda demi menjaga kesehatan. Selain itu, kebiasaaan membawa bekal dari rumah pun juga mempengaruhi kesehatan orang Jepang. Orang Jepang percaya bahwa bekal dari rumah merupakan bekal yang sehat dan murah.

Dalam penelitian ini telah dibahas mengenai pentingnya choumiryou dasar dalam mempengaruhi harapan hidup orang Jepang. Untuk selanjutnya, penelitian mengenai tema serupa juga dapat dikembangkan dengan ranah yang lebih mengkerucut. Contohnya membahas mengenai peran salah satu choumiryou dasar sashisuseso untuk kesehatan. Selain itu dapat pula dibahas mengenai bagaimana pengaruh choumiryou asli Jepang dalam kuliner internasional. Pembahasan mengenai masakan Jepang hendaknya lebih banyak dilakukan agar berbagai hal di dalamnya dapat menjadi pengetahuan dan acuan dalam penelitian bidang kejepangan.

\section{Daftar pustaka}

Mardalis. 1999. Metode Penelitian Suatu Pendekatan Proposal. Jakarta: Bumi Aksara Matsuo, Makiko. 2013. Restructuring Japanese Food Safety Governance: Institutional Changes and Future Challenges. Berlin: Lexxion 
Poto, Margherita. 2010. Food Law Under The Rising Sun. Berlin: Lexxion

Rath, Eric C. 2010. Japanese Cuisine, a Backward Journey. California :University of California Press

Rath, Eric C. 2013. Reevaluating Rikyu: Kaiseki and the Origins of Japanese Cuisine. Seattle :The Society for Japanese Studies

Rumney, Thomas A. 2011. Food and Drink: Geograpical Studies. Ohio: International Society for Landscape, Place, \& Material Culture

Ross, Douglas E. 2011. Factors Influencing the Dining Habits of Japanese and Chinese Migrants at a British Columbia Salmon Cannery. New York: Springer

\section{Rujukan Internet:}

https://cookien.com/seasoning/ (19/06/19) 